\title{
Effects of malnutrition and sensory-motor stimulation on auditory evoked potentials
}

\author{
Juraci Gonçalves de Lima, Carolina Araújo Rodrigues Funayama, Luiz Marcellino de Oliveira ${ }^{\dagger}$, \\ Maria Rossato and José Fernando Colafêmina \\ Universidade de São Paulo, Ribeirão Preto, Brazil.
}

$\dagger$ in memoriam

\begin{abstract}
There is evidence that the auditory evoked potential (AEP) is altered by malnutrition both in laboratory animals and in humans. The objective of the present study was to determine whether changes in the AEP caused by malnutrition could be reversed by nutritional rehabilitation and sensorymotor and environmental stimulation during hospitalization. Six children aged 5-33 months with severe malnutrition (kwashiorkor, marasmus and marasmic-kwashiorkor) were admitted to the Pediatric Ward of a University Hospital. Normal age and sex-matched children from the hospital day-care center were enrolled as a control group. The AEP was tested in an electrically and acoustically isolated room using a Nicolet CA 2000 microcomputer. Clicks of 90; 80; 70 and $60 \mathrm{dBn}$ HL were presented through earphones. The results suggest that malnutrition leads to an increase in wave I latencies in patients with marasmus, and in waves I, III and V in those with kwashiorkor or marasmic-kwashiorkor type at $90 \mathrm{~dB}$ HL. At discharge, all but one patient with kwashiorkor showed reduced latencies of waves I, III and V compared to the values on admission. Despite the small sample, these preliminary results pointed out that the process of sensory stimulation used in our study in a properly directed, systematic and individualized manner showed encouraging results in terms of AEP recovery in these children. Keywords: malnutrition, infants, nutritional rehabilitation, auditory evoked potential, stimulation.
\end{abstract}

Received 30 September 2008; received in revised form 9 December 2008; accepted 16 December 2008. Available online 30 December 2008

\section{Introduction}

Many investigators have shown that nutrition is one of the basic factors for the development of the central nervous system (CNS) and that nutritional deficiency impairs CNS functioning (Bedi, 1987; Bedi, Thomas, Davies \& Dobbing, 1980; Cragg, 1972; Cravioto, Delicardie, \& Birch, 1966; Dobbing, 1968; Dobbing \& Sands, 1971; Finger \& Stein 1982; Lima, 1992; Mourek, Himwich, Myslivecet, \& Callison, 1967; Quirk, Mejya, Hesse, \& Su, 1995; Smart, Dobbing, Adlard, Linch, \& Sands, 1973; Sobotka, Cook, \& Brodie, 1974; Stein, Finger, \& Hart, 1983; Wang \& Xu, 2007).

There is evidence since the 1950's and 1960's that protein-calorie malnutrition is associated with retarded brain growth (Stock \& Smythe, 1963), reduced cerebral cellularity (Winick \& Rosso, 1969),

Juraci Gonçalves de Lima, Carolina Araújo Rodrigues Funayama, Luiz Marcellino de Oliveira, Maria Rossato and José Fernando Colafêmina - Universidade de São Paulo de Ribeirão Preto. Correspondence regarding this article should be directed to: Dr. Carolina A.R. Funayama - Universidade de São Paulo, Hospital das Clínicas, Ribeirão Preto, SP, Brazil, 14048-900. E-mail carfunay@fmrp.usp.br reduced myelination (Fishman, Prensky, \& Dodge, 1969) and, in the neurophysiological field, changes in electroencephalogram (Engel, 1956; Nelson \& Dean, 1959) and evoked potential tracings (Kawai, Nakamura, \& Matsuo, 1989; Flinn, Barnet, Lydick, \& Lackner, 1993; Hernández et al., in press).

Auditory Evoked Potentials (AEP) are very sensitive measures related to brain functions and have been used by many researchers with diverse objectives in humans, as in the pioneering studies by Hecox and Galambos (1974); and in experimental studies in animals (Buchwald \& Huang, 1975; Shipley, Buchwald, Norman, \& Guthrie, 1980; Plantz, Williston, \& Jewett, 1981).

It has been shown that early malnutrition (marasmus and kwashiorkor) produces marked alterations in the electrophysiological parameters of AEPs (Barnet et al., 1978; Bartel, Robinson, Conradie, \& Prinsloo, 1986). The study by Barnet et al. (1978) demonstrated that malnutrition of the marasmic type causes increased latencies of AEP waves that were considered to be irreversible since they were detected not only during the acute phase of malnutrition, but also after a long period of nutritional rehabilitation (12 months). Bartel et al. (1986) detected AEP abnormalities in children with kwashiorkor both during hospitalization and after 
the period of rehabilitation. The above data suggested that these abnormalities could be due to deficiencies in the myelination process that would result in decreased synaptic efficiency in the auditory system.

Some studies have shown CNS recovery in laboratory animals (Bedi \& Bhide, 1988; Renner \& Rosenzweig, 1987; Rocinholi, de Oliveira, \& Colafêmina, 2001), and it is well known that relatively simple programs of sensorymotor stimulation of malnourished children are effective in promoting a better development of these children (Carrazza et al., 1993; Grantham-McGregor, Powell, \& Walker, 1991; Grantham-McGregor, Schofield, \& Harris, 1983; Grantham-McGregor, Schofield, \& Powell, 1987; Granthan-McGregor, Stewart, \& Schofield, 1980; Nahar et al., in press; Walker, Chang, Powell, \& Grantham-McGregor, 2005).

Studies evaluating electrophysiological parameters have pointed to diverse nervous system compromise of auditory (Durmaz, Karagol, Deda, \& Onal, 1999; Vandana \& Tandon, 2006), visual (Durmaz et al., 1999; McDonald, Joffe, Barnet, \& Flinn, 2007), corticospinal (Karak, Misra, Garg, \& Katiyar, 1999), and somatosensory paths (Hesse, Rivera, de Díaz, \& Quirk, 1998), as well as inter-hemispheric modulation (Pinto \& Guedes, 2008), but no reference to the stimulation effects on evoked potentials in malnourished infants was found in the literature. Thus, the objective of the present study was to determine the effects of malnutrition (kwashiorkor, marasmus and marasmic-kwashiorkor) on AEPs and to establish whether changes could be reversed by nutritional rehabilitation associated with daily and individual sensorymotor and environmental stimulation.

\section{Methods}

\section{Participants}

After approval by the local Committee of Ethics and provision of signed informed consents by the adults responsible for the infants, the study was conducted on six children admitted to the Pediatric Unit of the University Hospital (HC) of Ribeirão Preto, São Paulo University, presenting one of the following types of malnutrition: kwashiorkor (cases $\mathrm{N} 1$ and N5), marasmus (N2 and N3) and marasmic kwashiorkor (N4 and N6) according to the classification of McLaren, Pleet and Read (1967). Data concerning the identification of the children at birth and during hospitalization are presented in Table 1. All patients but one (N4 - 2.300g - low weight at birth) were born at term with adequate weight for the gestational age, according to Sala (1977). The children were submitted to two AEP evaluations, one at admission and the other just before discharge from the hospital after nutritional rehabilitation. During hospitalization the children were submitted to sensory and environmental stimulation. Six healthy children matched by age and sex from the hospital day-care center were enrolled as controls. Control children were submitted to only one AEP evaluation after investigation of the middle ear by impedance measurement and by the stapes reflex. Subjects with other pathologies interfering with the air or sensorial ear conduction and presenting growth or neurodevelopmental problems were excluded from the study.

\section{Sensory-motor Stimulation}

Stimulating activities were performed as described by Celedon (1983), taking into account the children's age and development, evaluated by the Bayley Infant Development Scale (1993), soon after admission to the hospital. Based on the Bayley Scale psychomotor score, each child was assigned to an age group and the stimulation process was started with the activities listed in Table 2.

The children were submitted to daily stimulation sessions of one hour, between 1:30 and 2:30 pm, in a separate room prepared for the stimulation process. Three well-trained professionals were in charge of the stimulation process and received previous training in order to obtain agreement regarding the application of the technique proposed at the beginning of the study. During the first days of hospitalization, before the stimulation program, the three professionals took turns caring for each child, so that he/she would adapt to the new environment (the hospital) and to establish a process of child-stimulator interaction important for the fulfillment of the objectives proposed.

Table 1. Signs and symptoms of malnourished children Mo- months d- days *For the same age and sex of socioeconomic group IV of the table of Marques et al. (1974) ** MacLaren et al. (1967) + Present - Absent Kw-kwashiorkor MIII-marasmus degree III Mix - Marasmic-kwashiorkor.

\begin{tabular}{|c|c|c|c|c|c|c|c|c|c|c|c|c|}
\hline Patient & Age & Weight (g) & $\begin{array}{l}\text { Expected } \\
\text { Weight }(\mathrm{g})^{*}\end{array}$ & $\begin{array}{l}\text { Weight(g) } \\
\text { deficit }\end{array}$ & $\begin{array}{l}\text { Weight }(\mathrm{g}) \\
\text { discharge }\end{array}$ & Edema & $\begin{array}{l}\text { Skin } \\
\text { lesions }\end{array}$ & $\begin{array}{l}\text { Hair } \\
\text { changes }\end{array}$ & Hepatomegaly & Albumin $(\mathrm{g} / \mathrm{dl})$ & Points** & Class \\
\hline N1 F & $20 \mathrm{mo} 9 \mathrm{~d}$ & 9190 & 11862 & 2253 & 10180 & + & - & + & - & 3,4 & 10 & $\mathrm{Kw}$ \\
\hline $\mathrm{N} 2 \mathrm{M}$ & $6 \mathrm{mo} 27 \mathrm{~d}$ & 4840 & 8278 & 4153 & 6740 & - & + & - & - & 6 & 5 & M III \\
\hline N3 M & $7 \mathrm{mo} 8 \mathrm{~d}$ & 3700 & 8278 & 5531 & 5760 & - & - & + & - & 4 & 5 & MIII \\
\hline N4 M & $5 \mathrm{mo} 26 \mathrm{~d}$ & 4200 & 7387 & 4314 & 5190 & + & + & - & + & 6,7 & 8 & Mix \\
\hline $\mathrm{N} 5 \mathrm{~F}$ & $34 \mathrm{mo} 5 \mathrm{~d}$ & 7820 & 14869 & 4741 & 9400 & + & - & + & + & 4 & 10 & $\mathrm{Kw}$ \\
\hline N6 F & $4 \mathrm{mo} 26 \mathrm{~d}$ & 2760 & 6810 & 5983 & 4570 & - & + & + & + & 6,7 & 6 & Mix \\
\hline
\end{tabular}


Table 2. Objectives proposed and activities in the process of sensorymotor stimulation of children at different age ranges. DD dorsal decubitus VD-ventral decubitus.

OBJECTIVES AND ACTIVITIES

0-3 months

To acquire prehension, visual, auditory integration and cervical control: - hold objects of different shapes, sizes, colors, sounds. DD - follow a light source (large flashlight) and objects in the horizontal, vertical and circular directions. VD - follow light sources and objects in the vertical direction (up and down).

\section{4-5 months}

To facilitate object manipulation: - Exploration of different objects; VD: grasp objects at different heights; dorsal decubitus, grasp objects. To acquire schemes of trunk dislocation and balance: - placed now on the right, now the left; DD, with support under the axillae, bring to the sitting position in a movement cadenced on music. To acquisition and reinforcement of sound:- DD, rhythmic exercises in limb flexion and extension with the help of the sound, repeating casually emitted sounds.

\section{6-8 months}

To reinforce the sitting position and change in decubitus:-.sitting up, to manipulate and explore different and new objects. To stimulate crawling:- Sitting up, to turn to a ball thrown now to the left, now to the right. DD, try to reach objects placed now on the left, now on the right. DV, try to reach objects initially near and after more far.

\section{9-12 months}

To reinforce hand dexterity:- fit, stack up or group chips locks, rings, beating a drum; hit the keys of a piano with hands and fingers rhythmically imitating the examiner and orders. To place in the standing position and help to walk:- walk with support with two hands, then with one and then holding on to furniture. Acquisition of first words, attitudes:- point and name figures on cards (daddy, mommy, meow, bow wow). To recognize body parts: - Indicate parts of the body on him-herself or on a doll.

\section{3-18 months}

To reinforce activities of the previous group, increase coordination, improve fine movements and language: grasp and arrange balls, stack, fit and group smaller objects, model sand, clay, hug, blow a kiss, say please, say goodbye, dance and mimic.

\section{9-24 months}

To reinforce fine motor coordination and balance.:- object manipulation as in the previous stage, walk along a straight line and in a circle; walking, construct a line and a circle with an object on the head, jump, run, squat and rise to the sound of music, listen to stories and to construct sentences looking at illustrative figures.

Any activity to be performed with the child needed to be accepted by him/her and the sequence of activities was not rigid but depended on the interest and development of each child.

\section{AEP Evaluation}

Following regular otoscopic examination, the infants were evaluated in an electrically and acoustically isolated room. All of them received $16 \%$ chloral hydrate at the dose of $1.2 \mathrm{ml} / \mathrm{kg}$ body weight 30 minutes before the AEP test to reduce artifacts of muscular origin to a minimum and thus obtain satisfactory recordings before each evaluation. Brain stem electrical activities were recorded with three disk-shaped $\mathrm{Ag} / \mathrm{AgCl}$ electrodes using a Nicolet model CA 2000 microcomputer. The positive active electrode $(+)$ was placed on the region of the vertex of the skull (CZ), the common ground electrode on the frontal region of the head (FZ) and the negative electrode (-) on the earlobe homolateral to the test ear A1 (-) or A2 (-). Before installation of the electrode, the skin was cleaned with detergent and steel wool to remove necrotic and desquamating cells. To facilitate electrical conduction, a gelatinous substance of good electrolytic conduction was applied to the electrodes. The impedance between the electrodes was maintained below $5 \mathrm{k} \Omega$. The sound stimulation was presented through TDH-39 earphones 
and consisted of monaural rarefaction clicks generated by pulses of $100 \mu$ s duration. White noise was presented in the contralateral ear to mask with a differential of $40 \mathrm{dBn}$ HL between the two stimuli. The clicks were presented at stimulation rates of $11.4 / \mathrm{sec}$ at intensities of 90,80 , 70 and $60 \mathrm{dBn}$ HL, with a low filter (high - pass) of $150 \mathrm{~Hz}$ and high filter (low - pass) of $3000 \mathrm{HZ}$ (12 dB/ octave). The scanning speed was $100 \mathrm{~ms}$. Responses to 2000 clicks with an accepted rejection level of up to $20 \%$ were averaged and stored in a floppy disk, while wave latencies were simultaneously evaluated with a mobile cursor on the screen with digital reading. The data were plotted using a CITO HM 8510 printer/plotter.

\section{Statistics}

A paired t-test was used for the comparison of waves and interpeak latencies at different intensities of $\mathrm{dBn} \mathrm{HL}$, and qualitative analysis was performed taking into consideration the small sample.

\section{Results}

The mean latencies of the wave I, III and V and the interpeak intervals I-III, III-V and I-V are shown in Table 3 for $70 \mathrm{dBn}$ HL and in Table 4 for $90 \mathrm{dBn}$ HL. Only both levels, 70 and $90 \mathrm{dBn}$ HL, were presented, since the results for 60 and $70 \mathrm{dBn}$ HL were similar, as well as for 80 and $90 \mathrm{dBn}$ HL (t-test $\mathrm{p}>.05$ ).

Before the stimulation program and the nutritional treatment, patient N3 had a good registry for analysis only at $90 \mathrm{dBn} \mathrm{HL}$, and the latencies of waves I, III and $\mathrm{V}$ were lower than those obtained in the control infant. Patients N1 (kwashiorkor) and N4 (marasmickwashiorkor, the only one who was small according to the gestational age at birth in the sample) showed increases in latencies of waves I, III and V in both 90 and $70 \mathrm{dBn}$ HL. Patient N2 (marasmus degree III) showed increased latencies of wave I at $90 \mathrm{dBn} \mathrm{HL}$, and of waves I, III, V at 70 dBn HL. Patient N6 (marasmickwashiorkor) showed increase in the latency of waves I (90 dBn HL) and V (70 dBn HL); the other latencies were equivalent to those of controls in both levels. Patient N5 (kwashiorkor) showed increased latencies of wave V, and waves I and III similar to control at both 90 and $70 \mathrm{dBn}$ HL. At admission, the interpeak I-III was larger for N4 (both levels) and N1 (90 dBn HL); III-V for N5 (70 dBn HL), N1 and N6 (both levels); and I-V was larger for N6 (70 dBn HL) and N5 (both levels). At discharge, all but one infant (N1 - kwashiorkor) showed decrease in the latencies of waves I, III and $\mathrm{V}$, compared to the values at admission. The latencies of wave I remained above the respective controls for patients N1, N2, N3, N4, and N6 even at discharge (70 dBn HL). At discharge, five patients (N2, N3, N4, $\mathrm{N} 5, \mathrm{~N} 6)$ at $90 \mathrm{dBn} \mathrm{HL}$ and three (N4, N5 and N6) at $70 \mathrm{dBn}$ HL had latencies of waves III or V lower than their respective controls.

\section{Discussion}

Evidence that malnutrition causes changes in AEP measurements in children has been provided sparsely in the literature (Barnet et al., 1978; Bartel et al., 1986; Durmaz et al., 1999; Odabas et al., 2005).

Taking into account that the most used AEP reaches the level of the brainstem, studies involving higher paths and cortical areas are necessary, focusing on their vulnerability, damage, and persistence of the effects of malnutrition on higher cortical activity with present and future consequences for development. Flinn et al. (1993) investigated potentials recorded in cortical areas, with the child's name as a stimulus. They observed that malnourished infants had a lower number of wave peaks and amplitudes than controls, after a nutritional recovery period of about four months.

Although it is not our scope to address specific aspects of the stimulation procedure in this report, the effects of different types of stimuli on behavior (Cabral $\&$ Almeida, 2008), and the best results on visual learning when multisensory stimuli are presented in a congruent way (Kim, Seitz, \& Shams, 2008) are important issues for stimulation strategies in the clinical field.

As in the present work, in human clinical settings we can not attribute the results exclusively to the environmental and sensory stimulation, since nutritional treatment and medicines were often prescribed. To sort out such variables, methods in animal experiments have been developed. AEP analysis of handling stimulation without food supplementation in rats (Rocinholi et al., 2001) showed that stimulation alone reduced wave latencies, suggesting the possibility of reversion of some of the damage caused by malnutrition.

Despite different methodologies, it is worth to consider the similarity of our results in the control group to a Chinese sample (Jiang, Zheng, Sun, \& Liu, 1991) matched by age with the normative data at $70 \mathrm{dBn} \mathrm{HL}$, as well as to a Brazilian sample (Isaac, 1999) at $90 \mathrm{dBn}$ HL. Moreover, considering these two references, we found that among patients aged four to seven months, at admission and discharge, the values of latency of wave I were much higher than those of normal newborns, and that the two oldest patients (20 and 34 months of age) presented latencies of waves III and V around the values observed at 6 months age. Odabas et al. (2005) reported increased wave latencies (mainly for wave I) at all degrees of malnutrition. These findings suggest that malnutrition early in life may have a more marked effect on the caudal myelination of the auditory pathway. Wave I, according to Hecox and Galambos (1974), undergoes a process of maturation at about two or three months of life, and six months according to Isaac (1999). According to Salamy and McKean (1976), the significantly longer latency of wave I in newborns (six weeks of life), as compared to other age groups, suggests that the peripheral acoustic mechanisms are 
not fully developed in newborns, although it is not clear whether this initial delay in the latency of wave I is the result of immaturity of the middle and inner ear or of neuronal immaturity.

Concerning the interpeak latencies, our findings of kwashiorkor infants with III-V and I-V latencies longer than those of children with marasmus are in accordance with the findings of Durmaz et al. (1999). Bartel et al. (1986) found I-III, III-V and I-V intervals uniformly distributed among the degrees of malnutrition, studying 22 children, also showing differences between the two ears, which was further supported by Odabas et al. (2005). In the present sample we did not analyze the data for each ear.

The analysis of covariates in malnutrition and AEP studies has been rarely mentioned in the literature. The children's height was mentioned by Barnet et al. (1978), finding higher AEP waves amplitude in children with shorter stature. Other covariates, such as iron deficiency and albuminaemia, were analyzed by Odabas et al. (2005), showing in malnourished infants with iron deficiency longer than controls the mean latency of wave I on the left side and the mean III-V interpeak on the right side; in malnourished infants without iron deficiency, the mean I-III interpeak on the right ear was longer than controls, and no difference was found between low and normal serum albumin within the malnourished groups.

The SGA (small for gestational age) condition has not been studied among the possible confounding variables in the field of malnutrition. Odabas et al.
(2005) mention the exclusion of SGA infants in their criteria for subject selection. In the present study, the five-month-old patient who was born SGA, was the only one presenting increased I-III interpeak interval and above the control values at $70 \mathrm{dBn} \mathrm{HL}$, in both the admission and discharge AEP tracings, suggesting the need to examine the cochlear station since neonatal period for the SGA patients.

According to Bartel et al. (1986), AEP abnormalities were still evident after one year of nutritional followup of marasmic children, probably reflecting long-term effects of malnutrition on cerebral function. Durmaz et al. (1999) found different results comparing malnourished infants to controls on admission in a nutritional program and discharge. These authors reported differences at the time of admission, but not at discharge, in line with our results. In spite of the limitations of the present analysis, an interesting finding was the fact that the malnourished group showed lower latencies of waves I, III and V at discharge compared with the latencies at admission, and in three patients (one kwashiorkor) the latencies of waves III or $\mathrm{V}$ at discharge were lower than those of their respective controls. Thereby, we can suggest that the process of sensory and environmental stimulation may have been effective in bringing about a recovery from or prevention of the effects of malnutrition.

In conclusion, the present study suggests that the process of sensory stimulation used in a properly directed, systematic and individualized manner showed encouraging

Table 3. Latencies of waves I, III, V and interpeak values I-III, III-V and I-V recorded at $90 \mathrm{~dB}$ in six malnourished children and controls (C). A-admission D-discharge mo-months d-days.

\begin{tabular}{|c|c|c|c|c|c|c|c|}
\hline & & I & III & V & I-III & III-V & $\mathrm{I}-\mathrm{V}$ \\
\hline Case & Age & A $\quad$ D & A $\quad$ D & A $\quad$ D & A & A $\quad$ D & $\mathrm{D}$ \\
\hline N2 & $6 \mathrm{mo} 27 \mathrm{~d}$ & $2.31 \quad 1.72$ & $4.00 \quad 3.54$ & $5.93 \quad 6.02$ & $1.69 \quad 1.72$ & $1.93 \quad 2.62$ & $3.62 \quad 4.34$ \\
\hline $\mathrm{C} 2$ & $7 \mathrm{mo} 28 \mathrm{~d}$ & 1.69 & 4.00 & 6.36 & 2.31 & 2.36 & 4.67 \\
\hline N3 & $7 \mathrm{mo} 8 \mathrm{~d}$ & $1.58 \quad 1.60$ & $4.02 \quad 3.92$ & $5.92 \quad 5.84$ & $2.44 \quad 2.32$ & $1.90 \quad 1.92$ & $4.34 \quad 4.24$ \\
\hline $\mathrm{C} 3$ & $7 \mathrm{mo} 29 \mathrm{~d}$ & 1.69 & 4.00 & 6.36 & 2.31 & 2.36 & 4.67 \\
\hline N4 & $5 \mathrm{mo} 26 \mathrm{~d}$ & $2.26 \quad 1.74$ & $5.05 \quad 4.08$ & $6.72 \quad 5.52$ & $2.79 \quad 2.34$ & $1.67 \quad 1.44$ & $2.22 \quad 3.78$ \\
\hline $\mathrm{C} 4$ & $5 \mathrm{mo} 16 \mathrm{~d}$ & 1.56 & 4.11 & 6.40 & 2.55 & 2.29 & 4.84 \\
\hline N6 & $4 \mathrm{mo} 26 \mathrm{~d}$ & $1,99 \quad 2,10$ & $4.41 \quad 4.31$ & $6.09 \quad 6.15$ & $2.42 \quad 2.21$ & $1.68 \quad 1.84$ & $4.10 \quad 4.05$ \\
\hline C6 & 6 mo $2 d$ & 1,95 & 4.49 & 6.09 & 2.54 & 1.60 & 4.15 \\
\hline N1 & $20 \mathrm{mo} 9 \mathrm{~d}$ & $1.61 \quad 1.64$ & $3.98 \quad 4.02$ & $6.00 \quad 6.04$ & $2.37 \quad 2.38$ & $2.02 \quad 2.02$ & $4.39 \quad 4.40$ \\
\hline $\mathrm{C} 1$ & $21 \mathrm{mo}$ & 1.49 & 3.78 & 5.64 & 2.29 & 1.82 & 4.11 \\
\hline N5 & $34 \mathrm{mo} 5 \mathrm{~d}$ & $1.78 \quad 1.58$ & $3.92 \quad 3.78$ & $5.90 \quad 5.64$ & $2.17 \quad 2.20$ & $1.94 \quad 1.80$ & $4.12 \quad 4.06$ \\
\hline $\mathrm{C} 5$ & $34 \mathrm{mo} 2 \mathrm{~d}$ & 1.82 & 3.92 & 5.73 & 2.10 & 2.31 & 3.91 \\
\hline
\end{tabular}


Table 4. Wave latencies I, III, V and interpeak values I-III, III -V and I-V recorded at $70 \mathrm{~dB}$ in six malnourished children (N) and controls (C). A-admission D - discharge mo-months $\mathrm{d}$ - days.

\begin{tabular}{|c|c|c|c|c|c|c|c|}
\hline & & I & III & $\mathrm{V}$ & I-III & III $-\mathrm{V}$ & $\mathrm{I}-\mathrm{V}$ \\
\hline Case & Age & A $\quad$ D & $\mathrm{D}$ & $\mathrm{D}$ & $\mathrm{D}$ & $\mathrm{D}$ & $\mathrm{D}$ \\
\hline N2 & $6 \mathrm{mo} 27 \mathrm{~d}$ & $2.52 \quad 2.28$ & $4.43 \quad 3.90$ & $6.46 \quad 6.31$ & $1.91 \quad 1.25$ & $2.02 \quad 2.87$ & $3.94 \quad 4.12$ \\
\hline $\mathrm{C} 2$ & $7 \mathrm{mo} 28 \mathrm{~d}$ & 1.82 & 4.02 & 6.30 & 2.20 & 2.28 & 4.48 \\
\hline N3 & $7 \mathrm{mo} 8 \mathrm{~d}$ & $---\quad 1.91$ & $---\quad 4.37$ & $---\quad 6.30$ & 2.46 & 1.89 & 4.35 \\
\hline $\mathrm{C} 3$ & $7 \mathrm{mo} 29 \mathrm{~d}$ & 1.82 & 4.02 & 6.30 & 2.20 & 2.28 & 4.48 \\
\hline N4 & $5 \mathrm{mo} 26 \mathrm{~d}$ & 2.872 .00 & $5,68 \quad 4,42$ & $7.12 \quad 6.16$ & 2.812 .42 & $1.44 \quad 1.74$ & $4.25 \quad 4.16$ \\
\hline $\mathrm{C} 4$ & $5 \mathrm{mo} 16 \mathrm{~d}$ & 1.92 & 4,36 & 6.69 & 1.96 & 2.33 & 4.29 \\
\hline N6 & $4 \mathrm{mo} 26 \mathrm{~d}$ & $2,592,44$ & $4.78 \quad 4.80$ & $6.93 \quad 6.81$ & $2.19 \quad 2.36$ & $2.15 \quad 2.00$ & $4.34 \quad 4.36$ \\
\hline C6 & $6 \mathrm{mo} 2 \mathrm{~d}$ & 2,06 & 5.23 & 6.79 & 2.37 & 1.56 & 4.03 \\
\hline N1 & $20 \mathrm{mo} 9 \mathrm{~d}$ & $2.25 \quad 2.36$ & $4.26 \quad 4.53$ & $6.43 \quad 6.49$ & 1.902 .17 & $2.28 \quad 1.96$ & $4.18 \quad 4.14$ \\
\hline $\mathrm{C} 1$ & $21 \mathrm{mo}$ & 1.76 & 3.96 & 5.97 & 2.20 & 2.01 & 4.21 \\
\hline N5 & $34 \mathrm{mo} 5 \mathrm{~d}$ & 2.392 .07 & 4.634 .08 & $6.40 \quad 6.07$ & $2.20 \quad 2.01$ & $2.31 \quad 1.09$ & $4.01 \quad 4.00$ \\
\hline $\mathrm{C} 5$ & $34 \mathrm{mo} 2 \mathrm{~d}$ & 2.18 & 5.04 & 6.34 & 2.56 & 1.30 & 3.86 \\
\hline
\end{tabular}

results in terms of AEP recovery in these children. Even if they attend day-care centers using some type of stimulation, these children are exposed to a more collective and not individually directed process.

\section{Acknowledgements}

The authors owe debts of gratitude to Psychologist Dorothy Bono, Dr Naul Motta de Souza, and the staff of the Pediatrics Ward at the University Hospital of Ribeirão Preto, São Paulo University.

\section{References}

Barnet, A.B., Weiss, I.P., Sotillo, M.V., Ohbrich, E.S., Srkuvich, M.Z., \& Cravioto, J. (1978). Abnormal auditory evoked potentials in early infancy malnutrition. Science, 201(4354), 450-452.

Bartel, P.R., Robinson, E., Conradie, J.M., \& Prinsloo, J.G. (1986). Brainstem auditory evoked potentials in severely malnourished children with kwashiorkor. Neuropediatrics, 17(4), 178-182.

Bayley, N. (1993). Bayley scales of infant development. Texas: The Psychological Corporation.

Bedi, K.S. (1987). Lasting neuroanatomical changes following undernutrition during early life. In: J. Dobbing (Ed.), Early nutrition and later achievement (pp. 1-49). New York: Academic Press.

Bedi, K.S., \& Bhide, P.G. (1988). Effects of environmental diversity on brain morphology. Early Human Development, 17(2-3), 107143.

Bedi, K.S., Thomas, Y.M., Davies, A.A., \& Dobbing, J. (1980). Synapse-to-neuron ratios of the frontal and cerebellar cortex of 30-day-old and adult rats undernourished during early post natal life. Journal of Comparative Neurology, 193(1), 49-56.

Buchwald, J.S., \& Huang, C. (1975). Far-field acoustic response: origins in the cat. Science, 189(4200), 382-384.

Cabral, A., \& Almeida, S.S. (2008). Effects of tactile stimulation and underwater trauma on the behavior of protein-malnourished rats in the elevated plus-maze test. Psychology \& Neuroscience, 1(1), 63-66.

Carrazza, F.R., Patah, D., Marco, S., Godoy, C.M., Pieri, S., \& Issler, H. (1993) Normalização do Quociente de Desenvolvimento de lactantes desnutridos graves estimulados pelas suas mães. Revista Paulista de Pediatria, 11(2), 174-177.

Celedon, J.M. (1983). Nutrición e inteligencia en el niño. Santiago: Ediciones de la Universidad de Chile.

Cragg, B.G. (1972). The development of cortical synapses during starvation in the rat. Brain, 95(1), 143-150.

Cravioto, J., Delicardie, E.R., \& Birch, H.G. (1966). Nutrition, growth and neurointegrative development: an experimental and ecologic study. Pediatrics, 38(2), 319-367.

Dobbing, J. (1968). Effects of experimental undernutrition on development of the nervous system. In: N.S. Scrimshaw \& J.E. Gordon (Eds.), Malnutrition learning and behavior (pp. 181202). Cambridge: MIT Press.

Dobbing, J., \& Sands, J. (1971). Vulnerability of developing brain. IX. The effect of nutrition growth-retardation on the timing of the brain growth spurt. Biology of the Neonate, 19(4), 363-378.

Durmaz, S., Karagöl, U., Deda, G., \& Onal, M.Z. (1999). Brainstem auditory and visual evoked potentials in children with proteinenergy malnutrition. Pediatrics International, 41(6), 615-619.

Engel, R. (1956). Abnormal brain wave patterns in kwashiorkor Electroencephalography and Clinical Neurophysiology, 8(3), 489-500.

Finger, S., \& Stein, D.G. (1982). Brain Damage and recovery: research and clinical perspectives. New York: Academic Press.

Fishman, M.A., Prensky, A.L., \& Dodge, P.R. (1969). Low content of cerebral lipids in infants suffering from malnutrition. Nature, 221(5180), 552-553.

Flinn, J.M., Barnet, A.B., Lydick, S., \& Lackner, J. (1993). Infant malnutrition affects cortical auditory evoked potentials. Perceptual and Motor Skills, 76(3 Pt2), 1359-1362.

Grantham-McGregor, S., Powell, C.A., \& Walker, S.P. (1991). Nutritional supplementation, psychosocial stimulation and 
mental development of stunted children: the Jamaican study. Lancet, 338(8758), 1-5.

Grantham-McGregor, S., Schofield, W., \& Harris, L. (1983). Effect of phychosocial stimulation on mental development of severely malnourished children: an interim report. Pediatrics, 72(2), 239-243.

Grantham-McGregor, S., Schofield, W., \& Powell, C.A. (1987). Development of severely malnourished children who received psychosocial stimulation: six-year follow-up. Pediatrics, 79(2), 247-254.

Grantham-McGregor, S., Stewart, M.E., \& Schofield, W. (1980). Effect of long-term psychosocial stimulation on mental development of severely malnourished children. Lancet 2(8198), 785-789.

Hecox, K., \& Galambos, R. (1974). Brainstem auditory responses in human infants and adults. Archives of Otolaryngology, 99(1), 30-33.

Hernández, A., Burgos, H., Mondaca, M., Barra, R., Núñez, H., Pérez, H., Soto-Moyano, R, Sierralta, W., Fernández, V., Olivares, R., \& Valladares, L. (in press). Effect of prenatal protein malnutrition on long-term potentiation and BDNF protein expression in the rat entorrhinal cortex after neocortical and hippocampal tetanization. Neural Plasticity.

Hesse, H., Rivera, M.F., de Díaz, I., \& Quirk, G.J. (1998). Central somatosensory conduction time in severely growth-stunted children. American Journal of Clinical Nutrition, 67(1), 93-96.

Isaac, M.L. (1999) Estudo da maturação das vias auditivas por meio dos potenciais auditivos evocados de tronco cerebral em crianças pré-termo e a termo até 18 meses de idade. Unpublished Doctoral Thesis. Universidade de São Paulo.

Jiang, Z.O., Zheng, M.S., Sun, D.K., \& Liu, X.Y. (1991). Brainstem auditory evoked responses from birth to adulthood: normative date of latency and interval. Hear Research, 54(1), 67-74.

Karak, B., Misra, S., Garg, R.K., \& Katiyar, G.P. (1999). A study of transcranial magnetic stimulation in older ( $>3$ years) patients of malnutrition. Neurology India, 47(3), 229-233.

Kawai, S., Nakamura, H., \& Matsuo, T. (1989). Effects of early postnatal undernutrition on brainstem auditory evoked potentials in weanling rats. Biology of the Neonate, 55(4-5), 268-274.

Kim, R.S., Seitz, A.R., \& Shams, L. (2008). Benefits of Stimulus Congruency for Multisensory Facilitation of Visual Learning. PLoS ONE, 3(1), e1532. doi: 10.1371/ journal.pone.0001532.

Lima, J.G. (1992). Estudo morfológico e morfométrico do corpo caloso de ratos submetidos a diferentes tipos de dietas e à estimulação sensorial e ambiental. Unpublished Doctoral Thesis. Universidade de São Paulo.

Marques, R.M., Berquó, E., Yunes, J., \& Marcondes, E. (1974). Crescimento de crianças brasileiras: peso e altura segundo idade e sexo. Anais Nestlé, Suppl. 2.,

McDonald, C.G., Joffe, C.L., Barnet, A.B., \& Flinn, J.M. (2007). Abnormal flash visual evoked potentials in malnourished infants: an evaluation using principal component analysis. Clinical Neurophysiology, 118(4), 896-900.

McLaren, D.S., Pleet, P.L., \& Read, W.W.C. (1967). A simple scoring system for classifying the severe forms of protein-calorie malnutrition of early childhood. Lancet, 1(7489), 533-535.

Mourek, J., Himwich, W.A., Myslivecet, J., \& Callison, D.A. (1967). The role of nutrition in the development of evoked cortical responses in rat. Brain Research, 6(2), 241-251.

Nahar, B., Hamadani, J.D., Ahmed, T., Tofail, F., Rahman, A., Huda, S.N., \& Grantham-McGregor S.M. (in press). Effects of psychosocial stimulation on growth and development of severely malnourished children in a nutrition unit in Bangladesh. European Journal of Clinical Nutrition.

Nelson, G.K., \& Dean, R.F.A. (1959). The electroencephalogram in African children: Effects of kwashiorkor and a note on the newborn. Bulletin of the World Health Organization, 21, 77982.

Odabas, D., Caksen, H., Sar, S., Tombul, T., Kisli, M., Tuncer, O., Yuca, K., \& Yilmaz C. (2005). Auditory brainstem potentials in children with protein energy malnutrition. International Journal of Pediatric Otorhinolaryngology, 69(7), 923-8.

Pinto, A.V., \& Guedes, R.C. (2008). Direct evidence of interhemispheric modulation by callosal fibers: a cortical spreading depression study in wellnourished and early-malnourished adult rats. Experimental Brain Research, 186(1), 39-46.

Plantz, R.G., Williston, J.S., \& Jewett, D.L. (1981). Effects of undernutrition on development of far-field auditory brainstem responses in rat pups. Brain Research, 213(2), 326-329.

Quirk, G.L., Mejya, W.R., Hesse, H., \& Su, H. (1995). Early malnutrition followed by nutritional restoration lowers the conduction velocity and excitability of the corticospinal tract. Brain Research, 670(2), 277-282.

Renner, J.M., \& Rosenzweig, M.R. (1987). Enriched and impoverished environment: effects on brain and behavior. New York: SpringVerlag.

Rocinholi, L.F., de Oliveira, L.M., \& Colafêmina, J.F. (2001). Malnutrition and environmental stimulation in rats: wave latencies of the brainstem auditory evoked potentials. Nutritional Neuroscience, 4(3), 199-212.

Sala, M.M. de. (1977). Estudo do crescimento intrauterino na segunda metade da gestação. Determinação dos percentis $10^{\circ}, 25^{\circ}, 50^{\circ}$, $75^{\circ} \mathrm{e} 90^{\circ}$, do peso placentário, indice placentário, peso e estatura fetal. Unpublished Thesis. Universidade de São Paulo.

Salamy, A., \& Mckean, C.M. (1976). Postnatal development of human brainstem potentials during the first year of life. Electroencephalography and Clinical Neurophysiology, 40(4), 418-426.

Shipley, C., Buchwald, J.S., Norman, R., \& Guthrie, D. (1980). Brain stem auditory evoked response development in the kitten. Brain Research, 182(2), 313-26.

Smart, J.L., Dobbing, J., Adlard, B.P.F., Linch, A., \& Sands, J. (1973). Vulnerability of developing brain: Relative effects of growth restriction during the fetal and suckling periods on behavior and brain composition in adult rats. The Journal of Nutrition, 103(9), 1327-1338.

Sobotka, J., Cook, M.P., \& Brodie, R.E. (1974). Neonatal malnutrition: neurochemical hormonal and behavioral manifestations. Brain Research, 65(3), 443-457.

Stein, D.G., Finger, S., \& Hart, T. (1983). Brain damage and recovery: problems and perspectives. Behavioral and Neural Biology, 37(2), 185-222.

Stock, M.B., \& Smythe, P.M. (1963) Does undernutrition during infancy inhibit brain growth and subsequent intellectual development? Archives of Disease in Childhood, 38, 546-552.

Vandana, Tandon, O.P. (2006). Auditory evoked potential responses in chronic malnourished children. Indian Journal of Physiology \& Pharmacology, 50(1), 48-52.

Walker, S.P., Chang, S.M., Powell, C.A., \& Grantham-McGregor, S.M. (2005). Effects of early childhood psychosocial stimulation and nutritional supplementation on cognition and education in growth-stunted Jamaican children: prospective cohort study. Lancet, 366(9499), 1756-1758.

Wang, L., \& Xu, R.J. (2007). The effects of perinatal protein malnutrition on spatial learning and memory behaviour and brain-derived neurotrophic factor concentration in the brain tissue in young rats. Asia Pacific Journal of Clinical Nutrition, 16(1), 467-472.

Winick, M., \& Rosso, P. (1969). The effect of severe early malnutrition on cellular growth of human brain. Pediatric Research, 3(2), 181-184. 